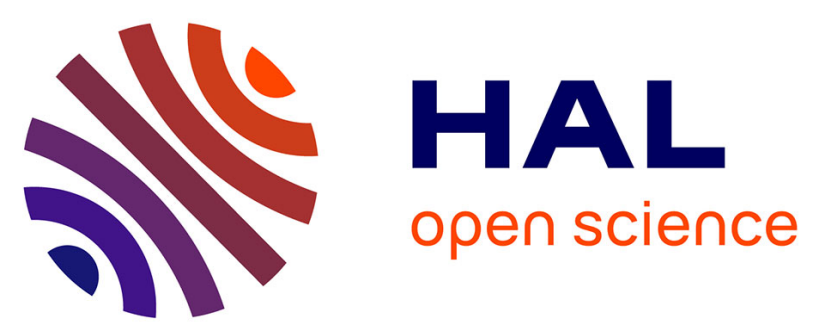

\title{
EFFECTS OF AN HYPOXIA AT 5\% OXYGEN ON GLOBAL ELECTROPHYSIOLOGICAL RESPONSES FROM NORMAL AND HYDROPIC EARS OF AWAKE GUINEA PIGS
}

\author{
Y. Cazals, Zy Wu, K. Horner
}

\section{To cite this version:}

Y. Cazals, Zy Wu, K. Horner. EFFECTS OF AN HYPOXIA AT 5\% OXYGEN ON GLOBAL ELECTROPHYSIOLOGICAL RESPONSES FROM NORMAL AND HYDROPIC EARS OF AWAKE GUINEA PIGS. Journal de Physique IV Proceedings, 1992, 02 (C1), pp.C1-253-C1-256. 10.1051/jp4:1992153 . jpa-00251224

HAL Id: jpa-00251224 https://hal.science/jpa-00251224

Submitted on 1 Jan 1992

HAL is a multi-disciplinary open access archive for the deposit and dissemination of scientific research documents, whether they are published or not. The documents may come from teaching and research institutions in France or abroad, or from public or private research centers.
L'archive ouverte pluridisciplinaire HAL, est destinée au dépôt et à la diffusion de documents scientifiques de niveau recherche, publiés ou non, émanant des établissements d'enseignement et de recherche français ou étrangers, des laboratoires publics ou privés. 


\title{
EFFECTS OF AN HYPOXIA AT 5\% OXYGEN ON GLOBAL ELECTROPHYSIOLOGICAL RESPONSES FROM NORMAL AND HYDROPIC EARS OF AWAKE GUINEA PIGS
}

\author{
Y. CAZALS, ZY WU and K. HORNER \\ Laboratoire d'Audiologie Expérimentale, Inserm unité 229, Université Bordeaux II, Hôpital Pellegrin, \\ F-33076 Bordeaux cedex, France
}

\section{SUMMARY}

In the continuation of our studies on the involvement of blood supply deficiencies in various experimental pathologies of the inner ear we have conducted a study on the effects of transient hypoxia on normal and hydropic ears. In the same study we investigated the possible protective effects of an antiischemic drug. All experiments were conducted on awake guinea pigs warranting a normal physiological functioning of the circulatory system. Global electrophysiological responses from the inner ear were monitored: cochlear microphonic, summating potential and auditory nerve compound action potential. In normal ears hypoxia induced a threshold elevation at all frequencies thus affecting the whole cochlea, and also very large diminutions of action potential amplitude evoked at high intensity level exclusively in response to a high frequency. Hydropic ears presented an hypersensity to anoxia, their action potential amplitude being affected at more stimulus frequencies and presenting a much slower recovery process, but their threshold elevations were similar to those of normal ears. The drug treatment limited the decrease of action potential amplitude in normals, but no such effect was observed for hydropic ears.

\section{RESUME}

Dans la continuation de nos études sur l'implication de troubles vasculaires dans différentes pathologies expérimentales de l'oreille interne nous avons étudié les effets d'une hypoxie transitoire sur des oreilles normales et hydropiques. Dans la même étude nous avons examiné les effets protecteurs éventuels d'un médicament anti-ischémique. Les expériences ont été réalisées sur des animaux éveillés ce qui garantit un fonctionnement normal des contrôles circulatoires. Les réponses électrophysiologiques globales de l'oreille interne, microphonique, sommation et potentiel nerveux, ont été suivies en continu. Sur les oreilles normales l'hypoxie a produit une élévation de seuil à toutes les fréquences affectant donc l'ensemble de la cochlée, mais aussi une très forte diminution du potentiel nerveux évoqué à forte intensité par une fréquence aigue exclusivement. Les oreilles hydropiques ont présenté une hypersensibilité à l'anoxie, le potentiel nerveux étant affecté à plus de fréquences de stimulation et montrant une récupération plus lente, mais les élévations de seuils ont été semblables à celles observées sur les oreilles normales. Le traitement par médicament a limité la diminution du potentiel nerveux sur les oreilles normales mais on n'a pas observé d'effet sur les oreilles hydropiques. 


\section{INTRODUCTION}

Deficiencies in blood supply are extremely widespread in human population especially in the elderly. Involvement of vascular insufficiencies to the inner ear induced experimentally have long been known to produce drastic functional alterations $(1,2)$. An involvement of vascular disturbancies in various hearing disorders is often suspected and vasoactive drugs are largely used in the treatment of numerous hearing disorders. However even in experimental conditions measurements of cochlear blood flow and composition are technically cumbersome and the validity of the obtained data is always questionable due to the physiological alterations induced by the experimental procedures (3). In a series of recent experiments we undertook to study in awake guinea pigs, thus without doubt as to the normal physiological functioning of blood circulation system, electrophysiological alterations induced by some vasoactive drugs. Our studies involved not only normal ears but also ears affected by different experimental pathologies. We thus provided evidence of efficacy of noradrenalin related drugs on the ototoxicity of hugh doses of aspirin thus supporting the idea of involvement of the sympathetic innervation of the cochlea (4). In another study we detected some beneficial but limited effects of a long term treatment with a drug having some anti-ischemic properties on hydropic ears of guinea pigs (5). Such positive results lead us to pursue our experimental studies on the effects of vasoactive drugs on pathological ears in the awake guinea pig. In this perspective we report here on the effects of transient hypoxia on electrophysiological responses from normal and hydropic cochleas, in the same study we have included the test of a drug with anti-ischemic properties (6).

\section{MATERIALS AND METHODS}

Adult pigmented guinea pigs were used in this study. Two groups were constituted: a group of five normal animals to obtain normative data and a group of eight animals which had been operated to induce endolymphatic hydrops. Hydropic animals were taken after three months at the end of the first phase of hearing loss development when the very high frequencies start to show some loss but threshold at the best absolute sensitivity is still normal (7).

During a test session of hypoxia animals were put in a restraining box and their nose introduced in a little mask in which a tube delivered a mixture of $5 \%$ oxygen and $95 \%$ nitrogen. Electrophysiological recordings were made every ten minutes or less during an hour and a half. A test session started with half an hour of normal breathing, then the hypoxic mixture was delivered during half an hour and finally, the session ended with a half-hour of normal air breathing. Audiograms were taken at the beginning of the test session, during hypoxia and at the end of the test session, stimuli at octave frequencies from 0.5 to $32 \mathrm{kHz}$ were used. Every ten minutes recordings of action potential, summating potential and microphonic responses were taken and measured in response to tone bursts of 16,8 and $2 \mathrm{kHz}$ presented at a level of 80 dB SPL.

All animals were given daily during seven consecutive days an oral dose of 2.5 milligrams of trimetazidine per kilogram of body weight. Immediately after the last drug administration the animals underwent another test session.

\section{RESULTS}

It was found that, as expected, the normal ears reacted to hypoxia with a decrease of action potential amplitude at the high frequencies and threshold elevations at all frequencies. Simultaneous alterations of summating potentials and to a lesser extent of microphonic potentials were also observed. A large interindividual variability being present in the amplitude of responses for the different potentials, their values were expressed as a percentage of the amplitude observed just before hypoxia was started. In figure 1 are presented variations in amplitude of the compound action potential in response to the $16 \mathrm{kHz}$ tone burst for all the animals and the two test sessions. It can be seen that at the beginning of hypoxia a very rapid decrease led to almost nul values, but within five minutes of the hypoxia which lasted thirty minutes a considerable recovery of about fourty percent occured, and at the end of the session recovery was around eighty percent.

At variance the hydropic animals exhibited less recovery and for half of them at the end of the session action potential amplitude was between zero and fifty percent. At stimulus frequencies of 8 and 2 $\mathrm{kHz}$ almost no variation of action potential were observed for normal ears whereas in hydropic ears for the 8 $\mathrm{kHz}$ stimulus a transient decrease of about thirty percent occured. These differences between normal and hydropic ears in response amplitude at high intensities were not associated with clear differences in threshold, indeed for all ears threshold elevations of around twenty $\mathrm{dB}$ were observed at all frequencies.

As concerns the drug treatment we observed some beneficial effects on normal ears but not so on hydropic ears. In figure 1 comparison of results from test 1 and test 2 shows that for normals during test 2 the minima of amplitude decrease reached only twenty to fourty percent, no such effect was apparent for the 


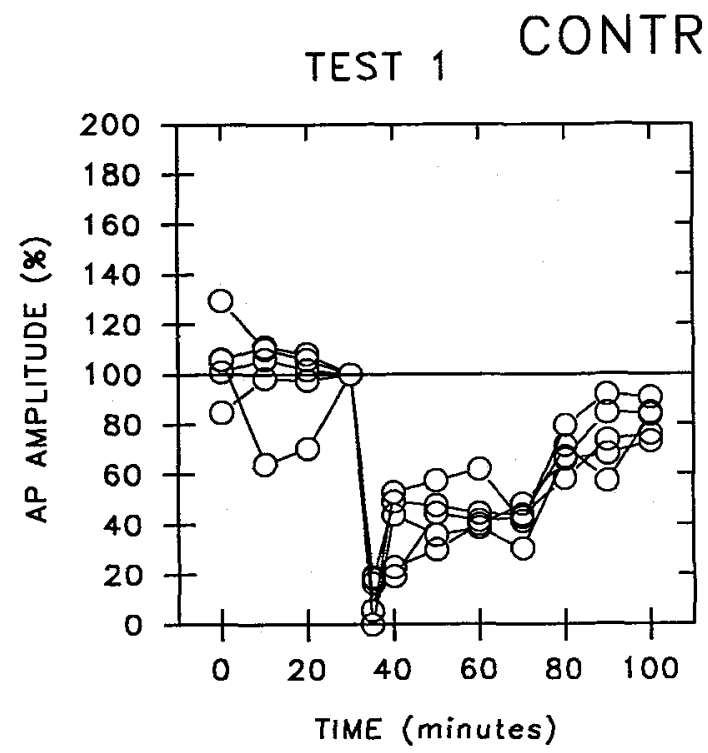

OL EARS TEST 2
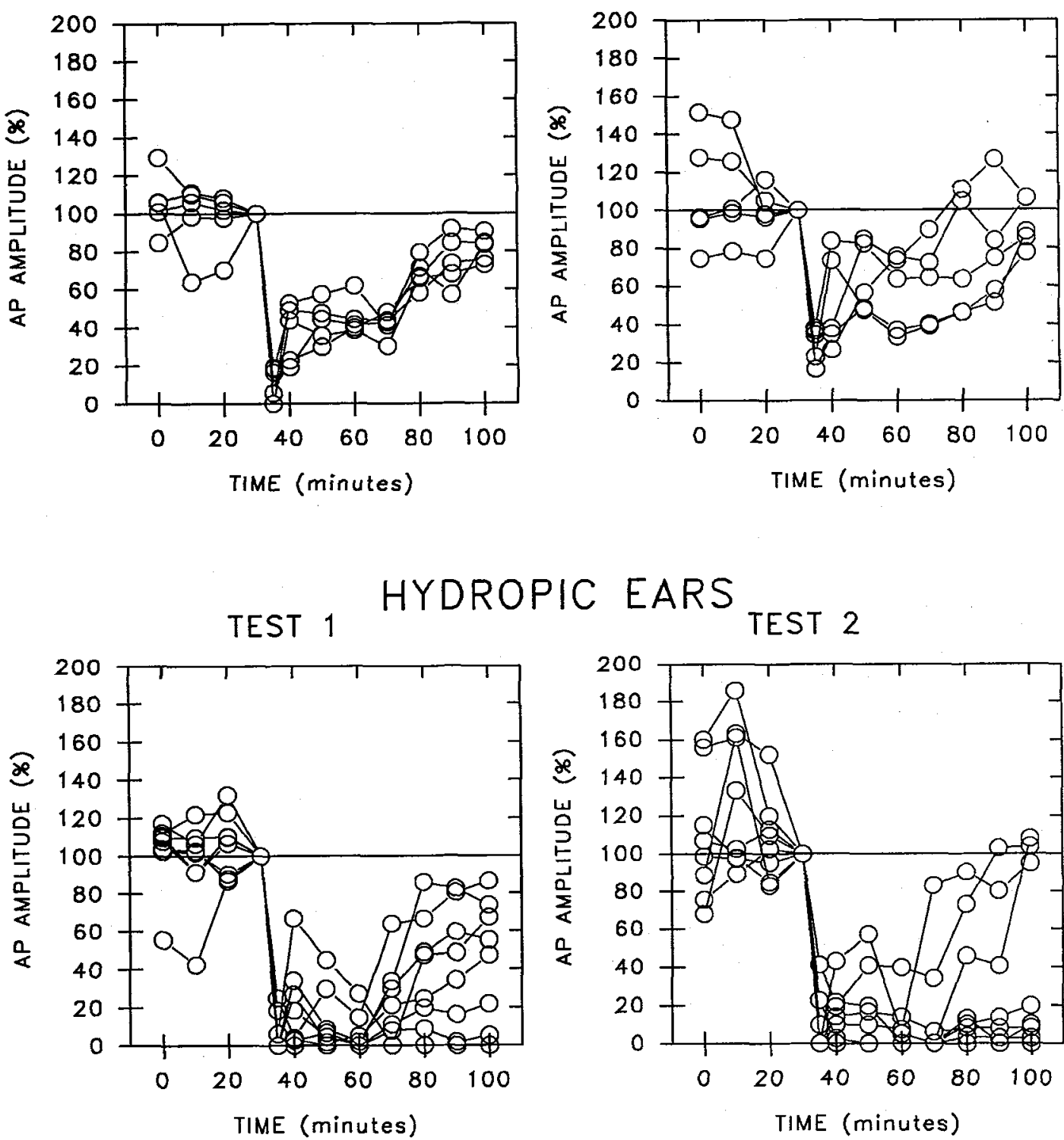

IC EARS TEST 2

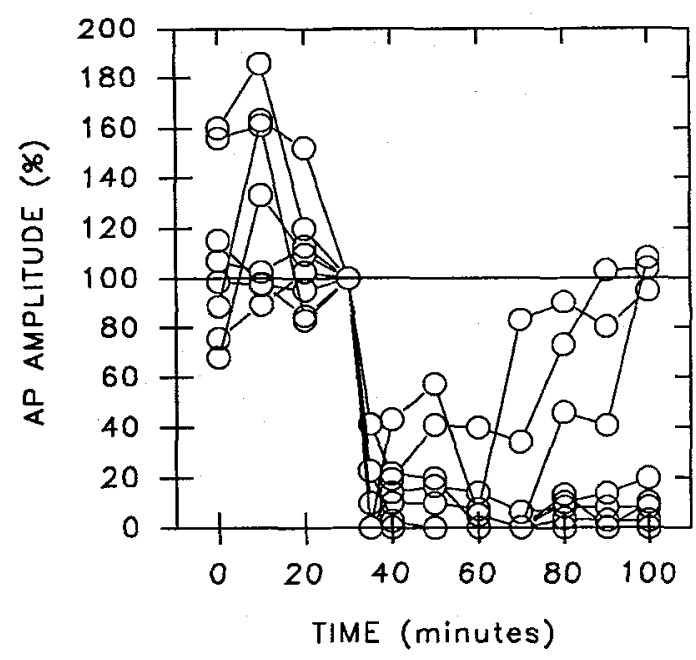

Amplitude variations of the compound action potential of the auditory nerve (in response to a $16 \mathrm{kHz}$ burst at $80 \mathrm{~dB}$ SPL) during test session of hypoxia $(5 \% \mathrm{O} 2-95 \% \mathrm{~N}$, starting at 30 and ending at 60 minutes). Both for the five control and eight hydropic ears, test 1 occured before and test 2 just after a oneweek treatment with a drug having anti-ischemic properties. 
hydropic ears as seen on the same figure 1. No other difference in response amplitude or threshold elevation was seen between test 1 and test 2 neither for the normals nor for the hydropic ears.

\section{DISCUSSION}

In the data presented here on normal ears on hypoxia, it was somewhat surprising to note that changes observed at high intensity were restricted to high frequencies whereas at low intensities (threshold) all frequencies were affected. This indicates two mechanisms of action of hypoxia: one acting all along the cochlea probably on outer hair cells, and a second one affecting in particular the cochlear base at high intensities and probably linked to inner hair cells. A few previous studies reported alterations of cochlear action potential in response to high intensity stimuli and dissociated from threshold changes, they concerned sympathectomy (8) and NMDA-type glutamate neurotransmission (9). At a cellular level alterations induced by hypoxia start with ATP decrease but come to affect all metabolic processes, including neurotransmission (10). We speculate that threshold elevations could be associated with overall energetic (ATP) decrease leading to diminution of endolymphatic resting potential. Action potential changes at high intensity and at cochlear base could reflect neurotransmission disturbancy: afferent, efferent or sympathetic.

The data reported here indicate from hydropic ears demonstrate an hypersensitivity to hypoxic conditions which affects the basal part of the cochlea. Indeed clear differences between normal and hydropic ears were observed in action potential and summating potential in response high intensity 16 and $8 \mathrm{kHz}$ tone bursts. An hypersensitivity of the base of hydropic cochleas to loud sounds has also been demonstrated recently (11). Both hypersensitivities may originate from a similar dysfunction likely related to abnormal metabolic fatigue under long lasting stress.

The beneficial effects of the drug restricted to changes at high frequencies and high intensity, since no effect was observed on thresholds, relates to the second mechanisms indicated above linked to inner hair cell function. The absence of effect of the drug on hydropic ears suggest they lack energetic reserves or regulatory processes.

\section{Acknowledgements}

Professor ZY WU participated in these experiments while he was was on leave for three months from his ENT Department at the First Affiliated Hospital in Wuhan, Hubei, China. The support of Biopharma laboratories is greatfully acknowledged.

\section{REFERENCES}

1 - Misrahy GA, Shinabarger EW and Arnold JE. Changes in cochlear endolymphatic oxygen availability, action potential and microphonics during and following asphyxia, hypoxia and exposure to loud sounds. J Acoust Soc Am, 30 , 701-704, 1958 .

2 - Konishi T, Butler RA and Fernandez C. Effects of anoxia on cochlear potentials. J Acoust Soc Am, 33, 349-356, 1961.

3 - Nuttall AL. Cochlear blood flow: measurement techniques. Am J Otolaryngol, 9, 291-301, 1988.

4 - Cazals Y, Li XQ, Aurousseau C and Didier A. Acute effects of noradrenalin related vasoactive agents on the ototoxicity of aspirin: an experimental study in the guinea pig. Hearing Reseach, 36, 89-96, 1988.

5 - Horner C, Cazals Y and Aurousseau C. Trivastal et oreille: études expérimentales chez le cobaye. Arch Otolaryngol., suppl juillet, 1989.

6 - Aubert A, Bernard C, Clauser P, Harpey C and Vaudry H. Anti-ischémique cellulaire, la trimétazidine prévient les effets délétères des radicaux libres de l'oxygène sur l'oreille interne. Ann Otolaryng, 107,28-35, 1990.

7 - Horner K, Guilhaume A and Cazals Y. Atrophy of short and middle stereocilia on outrer hair cells guinea pigs' cochleas with experimentally induced hydrops. Hearing Research, 32, 41-48, 1988.

8 - Hulcrantz E, Nuttall AL, Brown MC, Lawrence M. The effect of cervical sympathectomy on cochlear electrophysiology. Acta Otolaryngol, 94, 439-444, 1982.

9 - Puel JL and Pujol R. Selective glutamate antagonists block the excitotoxicity caused either by glutamate agonists or by ischemia. In "Auditory Physiology and Perception" eds Y Cazals, L Demany and C Horner. Pergamon press (in press) 1992.

10 - Benveniste H, Drejer J, Shousboe N, Diemer NH. Elevation of the extracellular concentration of glutamate and aspartate in rat hippocampus during transient cerebral ischemia monitored by intracerebral microdialysis. J Neurochem, 43, 1369-1374, 1984 .

11 - Horner K. Hypersensitivity of hydropic ears, at frequencies with normal thresholds, to temporary threshold shifts. Hearing Research 48, 281-286, 1990. 